\title{
Short trips and central places: The home-school distances in the Flemish primary education system (Belgium)
}

Kobe Boussauw****, Michiel van Meeteren* and Frank Witlox*

* Geography Department, Ghent University, Krijgslaan 281/S8, B-9000 Gent, Belgium

Tel.: +329264 4555 - Fax.: +3292644985

E-mail: kobe.boussauw@ugent.be, michiel.vanmeeteren@ugent.be, frank.witlox@ugent.be

** Civil Engineering Department, Centre for Mobility and Spatial Planning, Ghent University, Vrijdagmarkt 10/301, B-9000 Gent, Belgium

Tel.: +3293313250 - Fax. +3292645489

E-mail: kobe.boussauw@ugent.be

\section{Acknowledgements}

This paper draws from research conducted within the Policy Research Centre on Spatial Development, funded by the Flemish Government (Belgium). 


\begin{abstract}
This paper examines the extent to which home-school trip length in northern Belgium is influenced by the spatial distribution of the school sites, and to what extent this distribution contemporarily functions according to propositions of central place theory. Furthermore, from a sustainable mobility perspective, it is evaluated if the primary school network's density supports a daily urban system based on short distances. The results indicate that the overall system's density meets the requirements of a non-motorized system, while the distribution confirms central place mechanisms. The majority of the pupils live within walking or cycling distance from their school, while opportunities exist to further reduce this distance by choosing an alternative school. However, depending on the structure of the concerned settlement, school accessibility varies considerably. Finally, the results suggest that recent increases in school trip length and motorization are mainly caused by non-spatial factors.
\end{abstract}

\title{
Keywords
}

school travel

central place theory

spatial proximity

excess commuting

Flanders 


\section{Introduction: short trips and central places}

A considerable literature describes the relationship between the built environment and mobility patterns, in which the working hypothesis invariably assumes that a properly designed spatial structure can steer people's travel behaviour in a more sustainable direction (Banister et al., 1997; Stead and Marshall, 2001; Van Acker and Witlox, 2010). High residential density and thorough spatial mix of housing, amenities and jobs are usually considered spatial features that lead to less car use and shorter daily trips. Therefore, a high degree of spatial proximity is associated with a more sustainable form of daily mobility (Boussauw, 2011, p. 19).

However, the impact of spatial proximity on trips is highly dependent on the type of destination. The more specialized the trip end is, the greater the distance one is willing to cover and the less likely one wants to or will be able to exchange it for a similar destination closer to home (Berry et al., 1988). In Flanders, in the north of Belgium, for example, the average one-way commuting distance today amounts to 19 $\mathrm{km}$ (Janssens et al., 2011), while travel to less specialized destinations such as schools (primary, secondary and higher education combined: $9.5 \mathrm{~km})$ or shops $(3.5$ $\mathrm{km})$ is associated with shorter trip lengths.

These findings suggest that local, more or less generically available, services continue to play an important role in how daily urban systems are structured. The proximity to daily amenities such as supermarkets, bakeries, nurseries, schools and cultural and sports facilities, but also green space or transport network access points, largely determines the attractiveness of a particular residential precinct (Reginster and Goffette-Nagot, 2005). Additionally, the availability of proximate convenience amenities such as childcare or primary schools becomes more important as dual career households engage in ever more complex work-life balance puzzles (Karsten 2007; Van Diepen and Musterd, 2009).

The spatial influence of these daily amenities on travel behaviour is traditionally gauged through Central Place Theory (CPT), as developed by Christaller (1933[1966]). CPT provides a framework for an urban subsystem based on the relation between the specialization of central functions and the spatial reach of these functions. Central functions have a range consisting of a lower limit, which denotes 
the minimal size of the complementary area for the function to exist, and an upper limit, which indicates the maximum average distance a consumer wants to travel to procure a central function (Christaller 1933[1966], p. 22). Christaller (1933[1966], p. 20) took into account that what is considered a central function, as well as their respective upper and lower limits differ according to spatial and temporal context. Indeed, as individual transport became cheaper, people became more inclined to travel to alternative central places, further from their home, in order to have access to goods, services, or jobs better meeting their individual preferences (Lambooy, 1969). This observation made Hall (2002) to argue that the three lowest levels in the hierarchy of Christaller would no longer exist today altogether.

The work of Berry and Garrison (1958) made the applicability of CPT within expanding conurbations in the form of sub-centres in growing or grown residential areas around the traditional core city explicit. This approach was gradually incorporated in transport geography, where the term "polycentricity" was introduced to argue that sub-centres decrease aggregate car use (Cervero and $\mathrm{Wu}, 1997$ ). Subsequently, further cultivation of these sub-centres in terms of urban planning is regarded a sprawl-curbing urban development strategy (Bontje, 2004). The principle whereby spatial proximity is organized on the basis of an intra-urban polycentric structure is illustrated by Bertaud (2004) in his so-called "urban village" model. Bertaud acknowledges that this builds on the improbable hypothesis that people prefer the nearest available location to procure their central functions. In practice agglomerations often contain sub-centres, although consumers do not necessarily visit these in order to minimize their travel, a vision supported by the research of Krizek (2003), among others. Structures like the urban village model offer opportunities to strengthen spatial proximity between a number of services and the gravity centre of the residential area. For example, the presence of a range of schools in a suburb of a larger city will increase the likelihood that residents will not send their children to the city centre. When these facilities are clustered in sub-centres, it is likely that trips will be organized more efficiently (Cervero and Duncan, 2006). In the example, picking up the kids from school may be combined with a visit to the nearby supermarket. In contrast, a strong spatial distribution of facilities, without 
clustering, will also indicate a highly dispersed spatial structure that is associated with crisscross (car) traffic covering relatively large distances.

\section{Research question: The primary school as a neighbourhood level facility?}

Unlike Hall (2002), our research departs from the hypothesis that the low levels of the urban hierarchy still have relevance as a central place. We propose that the availability of daily facilities at the neighbourhood level may offer opportunities for a more sustainable urban and regional structure that facilitates short trips. From a planning perspective, the presence of a dense network of relatively small amenities may be considered a quality of place, through which accessibility can be maximized while avoiding excess (auto) mobility (Müller, 2011). Rather than the concept of the compact city, which is today perceived as overly naive (Neuman, 2005), the principle of short distances (in German known as "Stadt der kurzen Wege", and in French as "La ville des proximités") encompasses that also in suburban and rural areas facilities should be present within walking or cycling distance.

We test this hypothesis within the Flemish primary school system (for ages 6-12). Doing so, we consider the primary school as a generic amenity that is indicative of the centrality of the place where these are located. We can justify this choice on the basis of Christaller's definition of a central place of level M, who viewed these as centres in a catchment area of about 3000 inhabitants. While it would be naive to believe that the exact specifications of the hierarchical levels observed by Christaller still exist today, it is striking that an elementary school in Flanders serves on average 2820 inhabitants (Flemish Ministry of Education and Training, 2013), which is very close to the catchment size of Christaller's lowest level. Of course, a central place does not consist of only one single school, and it is outside the empirical scope of this paper to relate the geography of primary schools to other central functions. However, in practice we observe that primary schools in Belgium are often part of a cluster of local amenities, usually within the contours of a former or still existing village centre or urban sub-centre. Moreover, primary schools are not entirely generic facilities: in Belgium, parents often make a choice between a Catholic or a 
pluralistic ('official', which here means government organized) school where catholic schools are the majority due to historical reasons (see section 4).

From the general hypothesis that the neighbourhood level still matters, we put forward two research objectives:

1) To determine the extent to which home-school trip lengths are influenced by the spatial distribution of the school sites, and to what extent this distribution confirms the expectations of CPT.

2) To test whether the distribution of schools meets the requirements of a nonmotorized daily urban system based on short distances, across different urban contexts in northern Belgium.

The composition of the paper is as follows. First, we provide a brief overview of the spatial structure of the education system in Belgium and Flanders, relating this to the existing literature on home-school trips and school networks. We continue by describing the central place structure of northern Belgium with a particular focus on the contrasting examples of the cities of Bruges and Genk. Then, an empirical analysis is made of the home-school distances in the study area, both viewed from the location of the school, and from the place of residence of the pupil. The data are obtained from a recent centralized dataset that links the addresses of all pupils to the schools where they are enrolled. Both observed and shortest home-school distances are calculated using shortest-path analysis (Neutens et al., 2010). Subsequently we compare observed home-school distances with the shortest possible home-school distances, which determine the theoretical minimum catchment area when the school is considered a central function. The ratio between these two statistics is mapped, after which the hypothetical effect of urbanization on home-school distance is tested. By comparing the cases of Bruges and Genk, we will gauge how divergent central place structures of the cities influence the home-school commute of the individual pupil. 


\section{Schools, home-school distances and spatial structure: the northern Belgian context}

\subsection{School consolidation and home-school distances}

In many western countries, including Germany, the UK, the US, the Netherlands and Belgium, we observe a period of expansion of the school system, roughly until halfway the twentieth century, followed by a period of rationalization (De Boer, 2010 , p. 1). Maximizing accessibility of education in an era when mobility was limited was the core idea behind the expansion, which in practice meant the construction of additional schools making the school net denser in a geographical sense. Rationalization, which followed expansion, introduced business management logics in the organization of the education system, combining public service provision and economies of scale. This resulted in the closure of many smaller branches. In the post-1945 United States, the number of schools was reduced by no less than $70 \%$, while the average size of a school quintupled (Ewing and Greene, 2003). In countries where this rationalization was accompanied with a demographic surge of the school population, negative effects of school consolidation on spatial proximity and accessibility were largest.

In Belgium, the expansion of the school system continued steadily until rationalizations in 1957, when an absolute maximum of 9,029 primary schools was recorded (Leemans, 1998). According to Van Damme (1999), the so-called educational mini-rationalization in 1975 resulted in a reduction of the number of primary schools to 5000 within a few years, after which the school stock continued to shrink to about 4000 in the early nineties. When we link this evolution to demographic data, and express the figure in number of schools per 1000 children, it appears that the rationalization in fact started already two decades earlier (Fig. 1). 


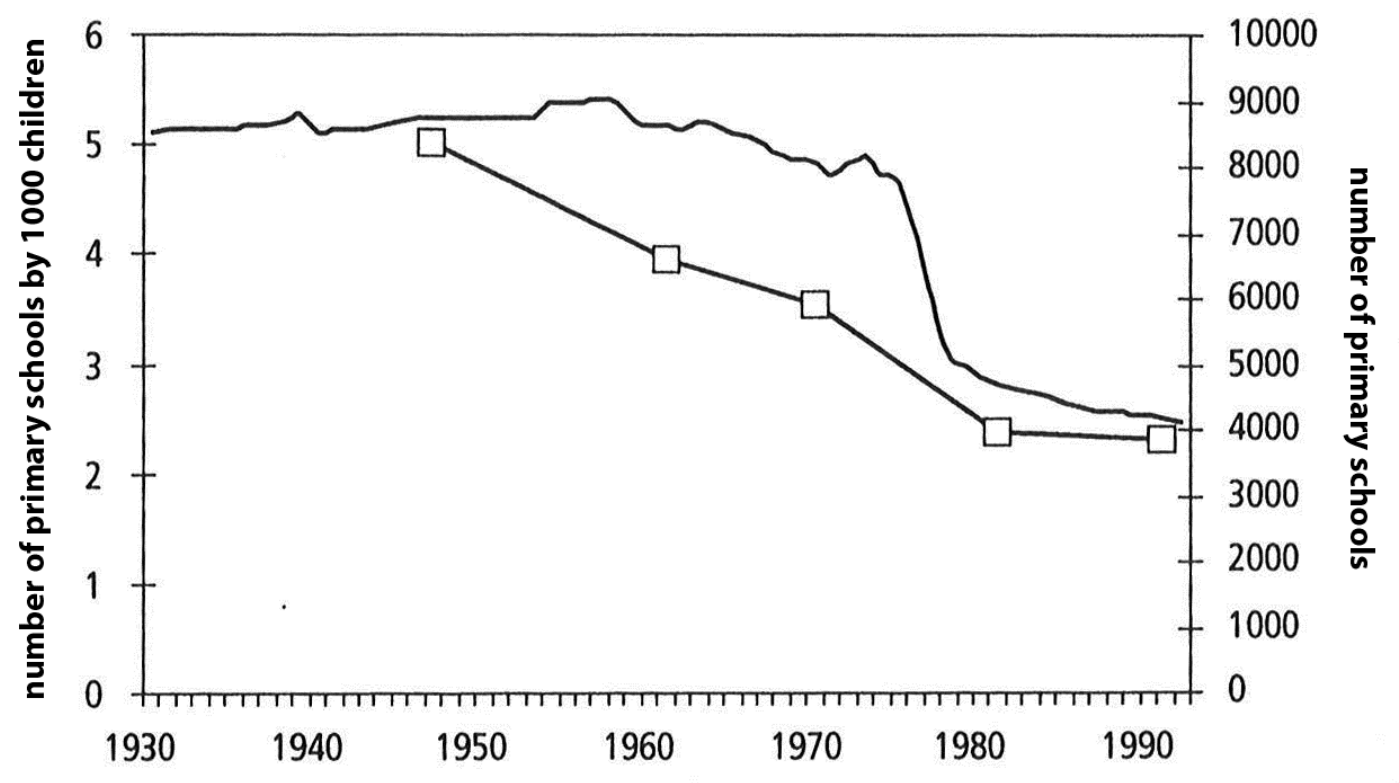

\section{$\neg \square$ by 1000 child. $\longrightarrow$ absolute number}

Fig. 1. Changes in the number of primary schools in Belgium (Van Damme, 1999)

Although the decrease in number of schools seems quite dramatic, the relatively low quality of the available data aggravates this observation somewhat. In historical statistics, one school does not correspond to one branch or one location. One school can cover multiple branches, and multiple schools may be administratively merged. Although the slowdown in the growth of the state budget for education in 1975 indicates that many schools effectively closed their doors, part of the rationalization probably occurred in the form of administrative consolidation of branches that were not necessarily accompanied with closures (Van Damme, 1999). While cutting back on the density of the school network was accompanied by an economic rationalization at the operational level of the school, undoubtedly also some externalization of costs was involved. An increase in average home-school distance means that students are less likely to walk or cycle to school, that the demand for organized transport increases and, particularly, that pupils become more likely to travel as a car passenger (Marique et al., 2013). On the other hand, this relation is not necessarily causal, as we will demonstrate below. Moreover, it is not inconceivable 
that school closure in small settlements has contributed to the disappearance of other amenities, such as retail.

In Flanders, nearly two-thirds of the school sites belong to the Catholic education network, while less than a third is part of the 'official' education system which is organized by the government. The expansion of the official school network was driven by the provision of the Belgian Constitution that school choice is free and that the state is obliged to offer neutral education to everyone (Van Houtte and Stevens, 2009). Although the quality standards and admission terms are equal in both systems, parents' preference for one of these two systems often influences the school choice. Finally, also some specialized education sites exist, including boarding schools. Since these are very rare, we do not distinguish such schools in our analysis. Although the choice of school is free, in many places schools face capacity constraints, obliging them to use waiting lists and deny candidate pupils. This phenomenon mainly occurs in the larger cities somewhat compromising our analysis.

\subsection{The development of the home-school distances in Flanders and Brussels}

The Belgian censuses of 1991 and 2001 assess trip lengths in school commuting. After 2001, the census was discontinued. In Table 1 we present the reported homeschool distance for pupils living in the Flanders region and the Brussels capital region according to census classification. The figures for the Brussels region are an average for pupils in Dutch-language and French-language schools.

Table 2 shows the main transport mode. Although this paper focuses on home-school distance, both tables suggest an influence of the distance to be covered on the mode choice, which is confirmed by Zwerts et al. (2010). Figures are retrieved from Mérenne-Schoemaker et al. (1999) and Halleux et al. (2009).

\begin{tabular}{|l|r|r|r|r|}
\hline & \multicolumn{2}{|c|}{1991} & \multicolumn{2}{|c|}{2001} \\
\hline & Flanders & Brussels & Flanders & Brussels \\
\hline $0-5 \mathrm{Km}$ & $83.1 \%$ & $89.3 \%$ & $76.2 \%$ & $77.2 \%$ \\
\hline $5-20 \mathrm{Km}$ & $15.3 \%$ & $10.1 \%$ & $20.9 \%$ & $20.7 \%$ \\
\hline $20-50 \mathrm{Km}$ & $1.5 \%$ & $0.5 \%$ & $2.4 \%$ & $1.7 \%$ \\
\hline$>50 \mathrm{Km}$ & $0.1 \%$ & $0.1 \%$ & $0.4 \%$ & $0.4 \%$ \\
\hline
\end{tabular}

Table 1. Distribution of home-school distances according to the censuses of 1991 and 2001 


\begin{tabular}{|l|r|r|r|r|}
\hline & \multicolumn{2}{|c|}{1991} & \multicolumn{2}{c|}{2001} \\
\hline & Flanders & Brussels & Flanders & Brussels \\
\hline on foot & $22.0 \%$ & $53.2 \%$ & $13.5 \%$ & $32.9 \%$ \\
\hline bicycle & $24.2 \%$ & $0.4 \%$ & $26.2 \%$ & $1.7 \%$ \\
\hline motorbike/moped & $0.0 \%$ & $0.0 \%$ & $0.0 \%$ & $0.0 \%$ \\
\hline auto & $39.1 \%$ & $31.7 \%$ & $50.1 \%$ & $43.6 \%$ \\
\hline organised transport & $10.3 \%$ & $3.7 \%$ & $5.7 \%$ & $4.2 \%$ \\
\hline bus/tram/metro & $4.2 \%$ & $10.8 \%$ & $4.2 \%$ & $17.2 \%$ \\
\hline train & $0.2 \%$ & $0.2 \%$ & $0.2 \%$ & $0.3 \%$ \\
\hline
\end{tabular}

Table 2. The distribution of modal choice according to the censuses of 1991 and 2001

In Flanders, home-school trip length has increased notably between 1991 and 2001. At the time of the census of 1991, more than $83 \%$ of the Flemish pupils in primary education lived less than $5 \mathrm{~km}$ from their school, while in 2001 this share had dropped to $76 \%$. Over the same period the share of car users in this group increased by $11 \%$, while the number of children going on foot decreased by as much as $39 \%$ (Halleux et al., 2009). It is worth to mention that currently, most regular schools are well served by the public transport system, making school buses organized by the schools or by the regional government a rather rare phenomenon. From our analysis, we know that the lower density of the official school network seems to have entailed slightly longer trip lengths, compared to the Catholic system, although this did not impact out general findings.

Only a small portion of the changes in the home-school travel pattern can be attributed to changing school density. In Flanders, in the period 1991-2001, no centrally organized closure of small branches in primary education was implemented, while in the same period the average home-school distance significantly increased. On the other hand, we know that in the 1970s and 1980s indeed quite a number of smaller branches have been closed.

This means that, along with the home-work commute (Dujardin et al., 2012), school mobility has been expanding a lot faster during the last hundred years than the spatial system itself was fanning out (Boussauw et al., 2011; Marique et al., 2013). Moreover, changes in travel behaviour have also encouraged school consolidation, 
and the residential structure too was slowly but surely fanning out in the course of decades, ending up on average further from traditional town and village centres. However, possible direct effects of school consolidation on home-school travel are not documented in Belgium. In the US, Ewing and Greene (2003) suggest that school consolidation and moving of schools outside urban centres certainly have played a major role in changing travel behaviour of schoolchildren.

\subsection{The central place system in northern Belgium}

Optimizing pupil allocations and determining optimal school locations is a classic subject in applied geography and planning (e.g. Stern and Michlis, 1986). However, in some systems, in particular the US (Glenn, 1989), students are allocated to a school rather than that free school choice dominates. When school choice is free, the principles of lower and upper boundaries of CPT apply, making it a valid application of CPT. Of course, the contemporary geography of central places is more complex than Christallers' stylized models tentatively suggest. There has been a tendency for central functions to scale-up, creating an urban system with far more complementarities and overlapping catchment areas than originally envisaged (Lambooy, 1969; Burger et al., 2013). However, this added complexity is not incongruent with the basic postulate of the theory. Christaller constructed his theory around the upper limit of central functions (Saey, 1973), implying that the higher population density of these overlaps logically entails a potentially higher degree of specialization of central functions within the complementary area (Christaller, 1966[1933], p. 33). A clustered distribution of a specific central function will give consumers a higher propensity to choose between different suppliers of a central function. Despite this upscaling, we still do expect to find variation of the central place system within Flanders. The historically evolved structure of central place systems bears the path-dependent traces of urbanization phases (Van Nuffel and Saey, 2005).

According to Van Nuffel and Saey (2005), the Flemish central place system shows three distinct patterns. The western part resembles Christaller's original hexagon scheme as a result of early urbanization in the medieval era. The central part, the economically dynamic area from Antwerp to Brussels, confirms broadly to 
Christaller's traffic principle. The eastern part only started urbanizing in the 19th century and shows a central place pattern much more strongly attenuated to car travel. To highlight the relevance of these historical differences and because zooming in on the municipality scale allows us to visually interpret individual home-school trajectories, section 5.2 will present two medium-sized cities and their surroundings as an illustration of the influence of the existing spatial structure on school choice. The choice of the two cities is based on their different genesis and subsequent spatial structure, making the two of them together rather representative of a variety of urban areas in Flanders. The first example is the city of Bruges (in the west), with a strong historical monocentric structure, which has become in the post-1945 period an agglomeration of about 170,000 inhabitants. The second example is the eastern city of Genk, which emerged only in the early twentieth century as the new centre of coal mining in the province of Limburg, consisting of a dispersed, suburban-style spatial structure that mainly developed in the post-1945 period. The Genk agglomeration comprises over 100,000 residents. Southwest of Genk, there is a second mediumsized city, Hasselt. The region east of Genk is mainly a forest area. Fig. 2 shows the northern Belgian urban system and highlights the two examples. The urbanization classes proposed in the map stem from the Spatial Plan for Flanders (RSV, 1997/2004), and are ordered from most to least urbanized: metropolitan area (MA), regional urban area (RUA), structure supporting small urban area (SSUA), small urban area at the provincial level (PSUA), nucleus in the outlying area (NOA) and outlying area (OA). 


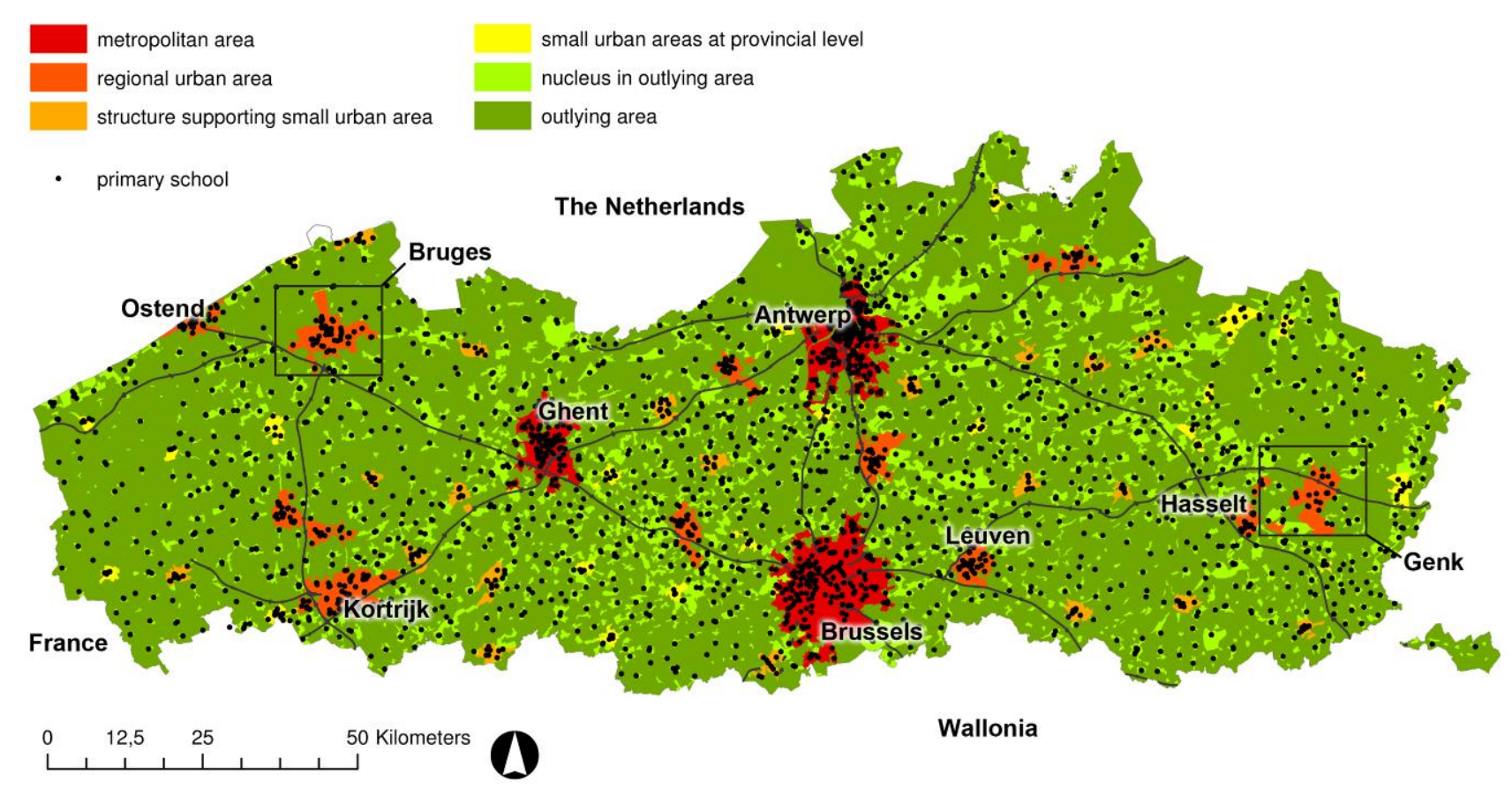

Fig. 2. Northern Belgium with urbanization classes according to the Spatial Plan for Flanders

\section{Method}

\subsection{Data and calculation of home-school distances}

Data for this study was provided by the Flemish Ministry of Education and Training.

The dataset contains addresses of each school branch and of the pupils who attended this school in February 2012. This single database allows the mapping of virtually all home-school relations within the Dutch-language (Flemish) education system with the highest possible accuracy and contains much more detail than the former censuses. However, the ministry does not collect information on the mode of transport chosen, neither on the chosen route.

In our analysis, only non-special needs schools are included, representing 388620 pupils or $93 \%$ of the total number. The students included in the database correspond with 2867 school locations, of which 128 are located in the Brussels-Capital Region and one in the Walloon Region. In the Brussels Region, the majority of education is 
provided by French-language schools. Since we have only been able to include Dutch-language schools, the analysis will be less relevant to the situation in Brussels. In order to simulate the home-school trajectories and distances from the linked addresses, the school addresses and the corresponding pupils were geocoded using an automated search of the Google Maps directory. In this context, it is important to mention that the home address registered in the database does not always match the address from where the child leaves for school on regular weekdays. For example, children of divorced parents may in reality live at different addresses, children can be registered at the address of the family's retreat residence, while some others are at boarding school or live with their grandparents during the week. On the other hand, there are also pupils who indeed travel large distances to school every day, especially when they ride with one of their parents to a school in the vicinity of the parent's work location. Such details are not documented in the dataset used. We have limited the impact of such biases as much as possible through the use of a judiciously chosen threshold of 40 kilometres. Pupils with a home address located further from the visited school are considered outliers and were omitted from the analysis. Moreover, those results from the geocoding process that were qualified by the software as less accurate, or where obvious errors were found, were omitted. This concerns $2.7 \%$ of the pupils and $1.0 \%$ of the schools. The remaining analysis relates to 374061 pupils, corresponding to 2837 school branches. Although past experiences teach us that even after such a meticulous correction erroneous geocoding remains inevitable, the large size of the dataset did not allow for manually correction of all suspected geocoding errors.

In order to calculate distances, the coordinates of residential and school locations were introduced in a GIS environment and linked to the road network (TeleAtlas' Streetnet). The applied network data also included the lowest category of roads, which are often local roads that are not suitable for through traffic but may be of importance for pedestrians and cyclists.

Using Network Analyst software (within an ArcGIS environment), for each student two home-school routes and corresponding distances were calculated. The first route is the result of a shortest-path calculation (Dijkstra algorithm) between the address of the pupil and the address of the school visited by this pupil, through the road 
network. In what follows, we denote the resulting figure as the "observed homeschool distance". The second route is a fictitious minimum home-school route, where each student is assigned to the primary school closest to home. This minimum homeschool route stems from the excess commuting literature (Horner, 2002), in which a comparison is made between the minimum distance that must be covered to reach a facility, and the distance that is covered in reality in order to visit a similar but alternative amenity (Boussauw et al., 2012). When calculating the resultant "minimum home-school distance", actual school capacity is not accounted for since in this theoretical exercise it is assumed that capacity follows demand.

\subsection{Analysis of the home-school distances}

The spatial analysis draws from the observed home-school distance and the minimum home-school distance. These variables are considered both from the perspective of the individual pupil and from the perspective of the school. From the school's point of view, apart from the average home-school distance also the median is calculated, which is more representative given the skewed distribution of the distances.

First, the exploration of the spatial distribution of the home-school distances is conducted in a cartographic and a quantitative way. In addition to a regional mapping approach by means of which the school sites are visualized, we zoom in to the contexts of Bruges and Genk where we will compare the shape and size of the school's catchment areas. This second mapping approach is used to visualize the home addresses of individual pupils in relation to the clustered central place context of Bruges and the relatively dispersed one of Genk. Subsequently, the data are grouped and compared according to the classes of urbanization as used in the Spatial Plan for Flanders (RSV, 1997/2004), as illustrated in Fig. 2. Based on this, conclusions are drawn regarding the two research objectives. 


\section{Spatial distribution of home-school distances}

\subsection{The perspective of the schools' locations}

Fig. 3 gives an overview of the involved schools, classified according to the median observed home-school distance. Fig. 4 shows the median minimum home-school distance, while Fig. 5 displays the ratio between the first-mentioned and the second variable, the so-called excess rate. Apart from the location of the schools, these maps also contain the municipal boundaries and major motorways, as a reference. The maps use quantile classification, reflecting the diversity of the data as well as possible. It is important to note that the minimum home-school distance and the excess rate are much more abstract concepts than the observed home-school distance, which justifies the use of different class thresholds. In Table 3, a number of key figures are given for the three mapped variables. Table 4 provides a breakdown of the same statistics according to degree of urbanization.

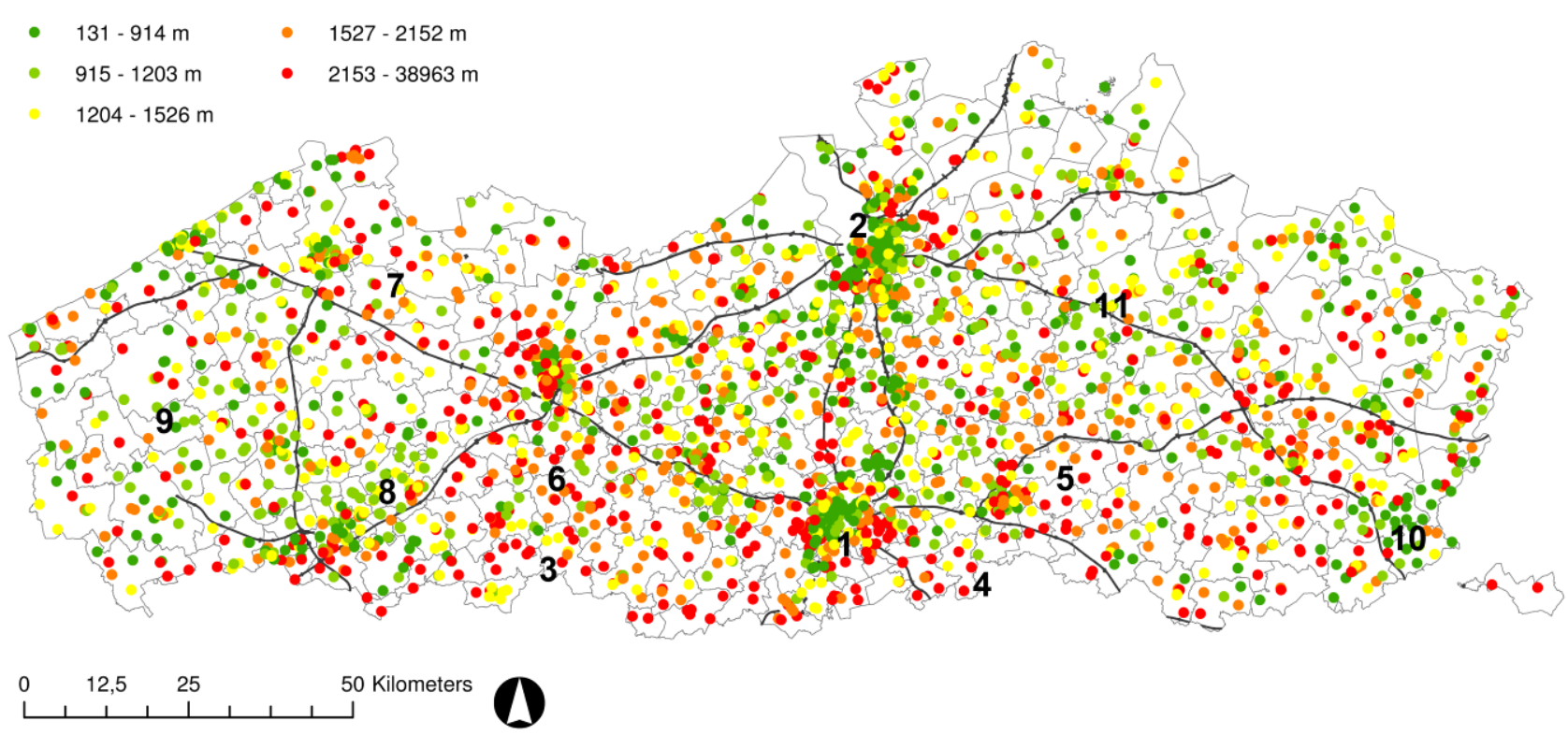

Fig. 3. Median observed home-school distance by school 

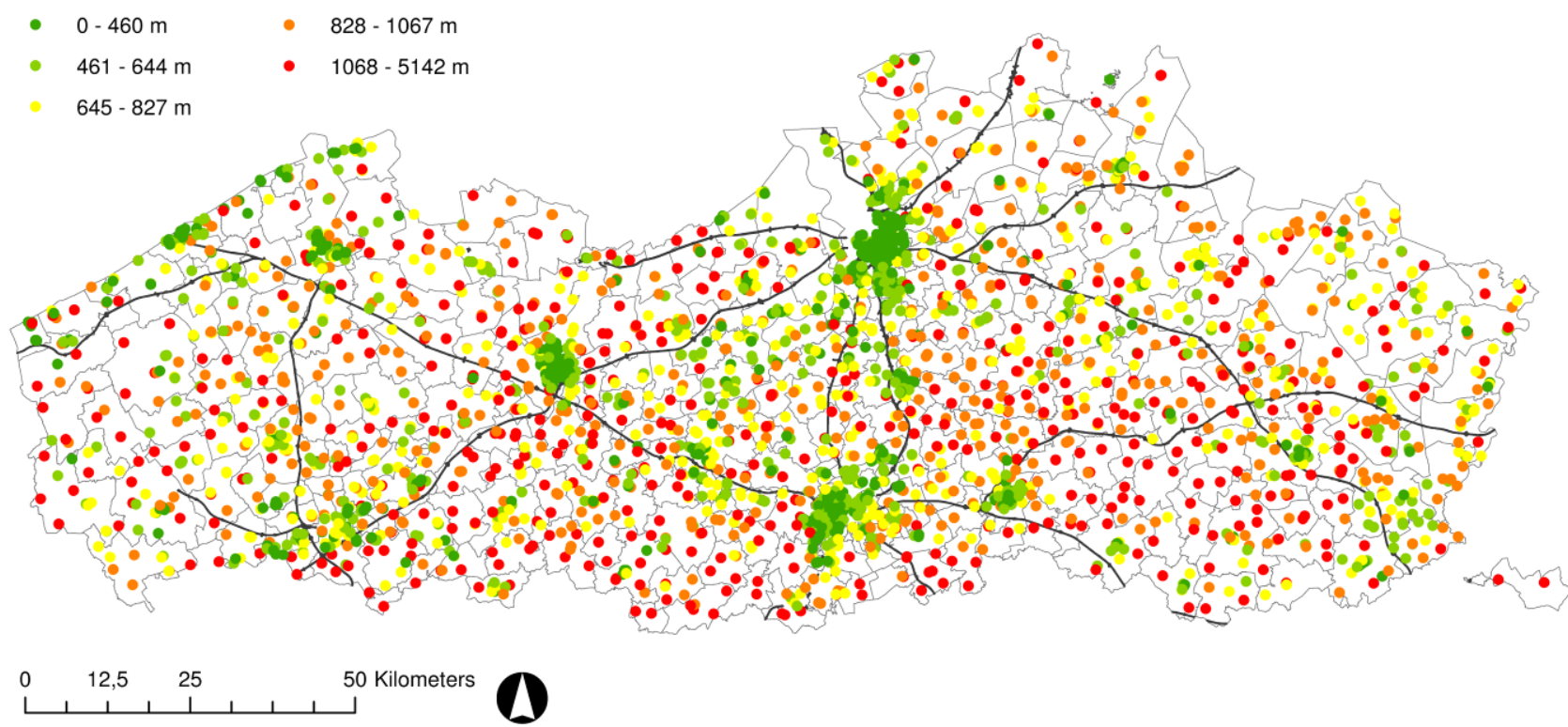

Fig. 4. Median minimum home-school distance by school

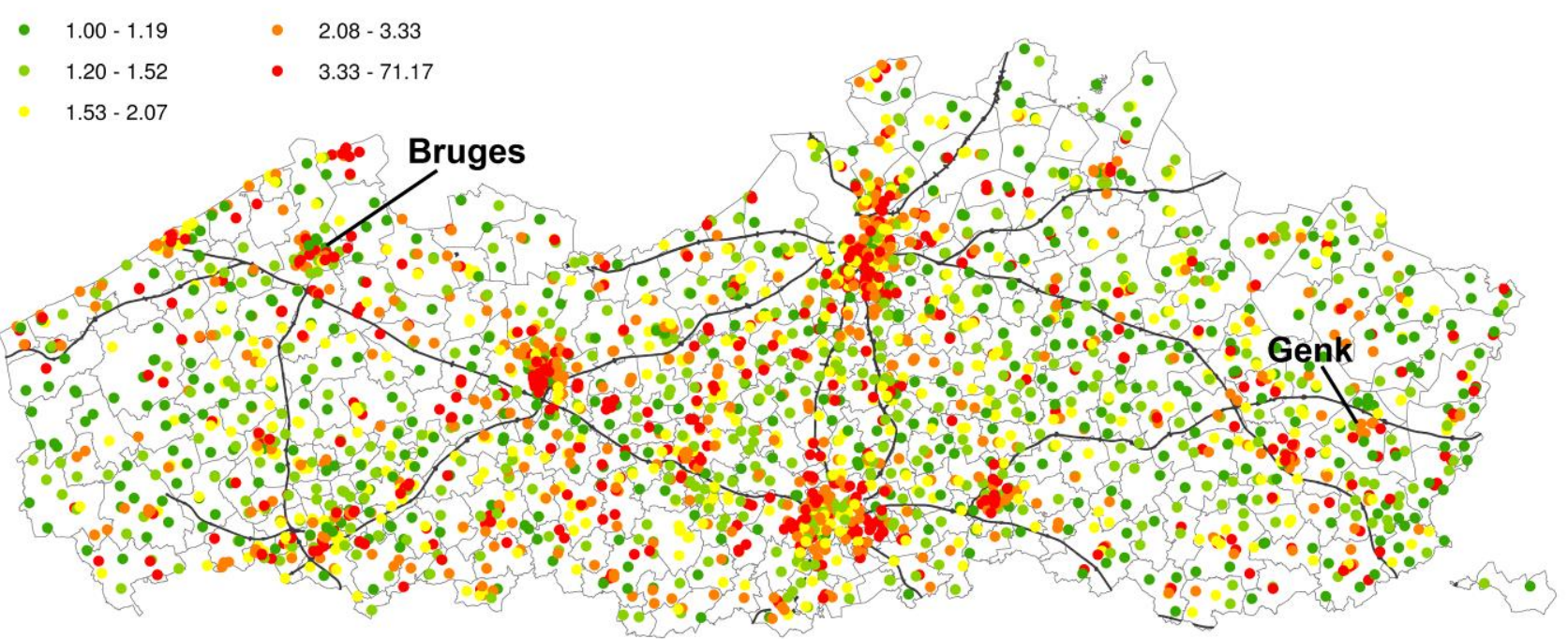

$\begin{array}{llll}0 & 5 & 10 & 20 \text { Kilometers }\end{array}$

பـபـப

$\mathbf{D}$

Fig. 5. Excess rate by school 


\begin{tabular}{|l|r|r|r|r|}
\hline & $\begin{array}{r}\text { observed } \\
\text { home-school } \\
\text { distance }\end{array}$ & $\begin{array}{r}\text { minimum } \\
\text { home-school } \\
\text { distance }\end{array}$ & excess rate & $\begin{array}{r}\text { number of } \\
\text { pupils }\end{array}$ \\
\hline median & $1346 \mathrm{~m}$ & $734 \mathrm{~m}$ & 1.76 & 122 \\
\hline mean & $1808 \mathrm{~m}$ & $806 \mathrm{~m}$ & 2.76 & 136 \\
\hline $\begin{array}{l}\text { standard } \\
\text { deviation }\end{array}$ & $2256 \mathrm{~m}$ & $455 \mathrm{~m}$ & 4.01 & 80 \\
\hline
\end{tabular}

Table 3. Statistics calculated on aggregate median observed and minimum homeschool distances by school, and the number of pupils per school

\begin{tabular}{|l|r|r|r|r|r|r|}
\hline class & MA & RUA & SSUA & PSUA & NOA & OA \\
\hline number of schools & 523 & 349 & 178 & 138 & 1513 & 136 \\
\hline $\begin{array}{l}\text { median observed } \\
\text { home-school distance }\end{array}$ & $1144 \mathrm{~m}$ & $1240 \mathrm{~m}$ & $1488 \mathrm{~m}$ & $1366 \mathrm{~m}$ & $1355 \mathrm{~m}$ & $2035 \mathrm{~m}$ \\
\hline $\begin{array}{l}\text { median minimum } \\
\text { home-school distance }\end{array}$ & $442 \mathrm{~m}$ & $562 \mathrm{~m}$ & $658 \mathrm{~m}$ & $704 \mathrm{~m}$ & $865 \mathrm{~m}$ & $1068 \mathrm{~m}$ \\
\hline $\begin{array}{l}\text { median number of } \\
\text { pupils per school }\end{array}$ & 140 & 130 & 126 & 136 & 112 & 103 \\
\hline median excess rate & 2.45 & 2.18 & 2.16 & 1.81 & 1.49 & 1.76 \\
\hline
\end{tabular}

Table 4. Statistics calculated on aggregate median observed and minimum homeschool distances by school, and the number of pupils per school, breakdown according to degree of urbanization

In Fig. 3, following items stand out:

- In the dense residential neighbourhoods of the larger cities, particularly in Brussels (1) and Antwerp (2), children are more often living in the immediate vicinity of their schools.

- In the suburban neighbourhoods of these cities, as well as in urban schools that are located near major motorways and arterial roads, home-school distances are above average.

- In the vicinity of the Belgian Dutch-French language border (3 and 4), where many schools are populated by Dutch-speaking pupils living in the French speaking southern part of Belgium, the observed distances are large.

- In the more rural areas we see strong variations in home-school distances, which may not always be grasped in clear structures. In some regions, distances are well above average, as is the case in the Hageland (5), Flemish 
Ardennes (6) and Meetjesland (7). In other regions, average distances are below average, which is obvious in the Leie-region (8), Westhoek (9), the southeastern part of the Limburg province (10) and parts of the Kempen (11).

Fig. 4 gives a clear picture of the morphological structure, making clear that the school network's density is closely related to the population's distribution. The following issues arrest attention:

- Both in larger cities and in smaller towns, the school network appears to be sufficiently dense from the point of view of offering children the opportunity to visit a school within walking distance.

- In the more rural areas, where both housing is more dispersed and the school network is less dense, pupils have to make longer trips, even if they visit the nearest school.

Fig. 5 combines both variables into the excess rate, which indicates the extent to which a school recruits pupils living in the immediate vicinity.

- Mainly in the cities we observe that the schools are usually populated by children who do not visit the nearest school. The presence of more opportunities within a short distance, typical of urban areas, allows parents to be more critical in choosing a particular school. This corroborates both the excess commuting literature and CPT: more suppliers within the upper limit of a central function allows for choice and potential specialization. In addition, capacity constraints also play a role, excluding certain schools from the choice range. A third reason is that urban schools are more often located in a destination area for daily commuter flows, meaning that commuting parents will be inclined to drive their children to a school near their work place.

- In contrast, in outlying areas schools are more often populated by children visiting the nearest or the second nearest school.

From Table 3, we infer that an average school recruits its students within less than $1800 \mathrm{~m}$ from the school, but that this distance would be reduced to about $800 \mathrm{~m}$ in a geographically optimized system. Table 4 shows that schools in metropolitan and regional urban areas recruit their students within relatively short distance. The 
minority of schools that are not located in an urban or village centre recruit their pupils from much larger distances.

\subsection{The perspective of pupils' home addresses}

For Bruges and Genk, Fig. 6 and 7 show an overview of the residences of the pupils concerned, classified according to the individually observed home-school distance. Fig. 8 and 9 show the minimum home-school distance per student, while Fig. 10 and 11 again provide the ratio between the first and the second variable, the so-called excess rate. In addition to the pupil's residences, these maps also include the road network that was used to calculate the routes, as a reference.

In Table 5 a number of key figures are given for the three mapped variables, while in Table 6 for each of the variables spatial variations are assessed in relation to the degree of urbanization.

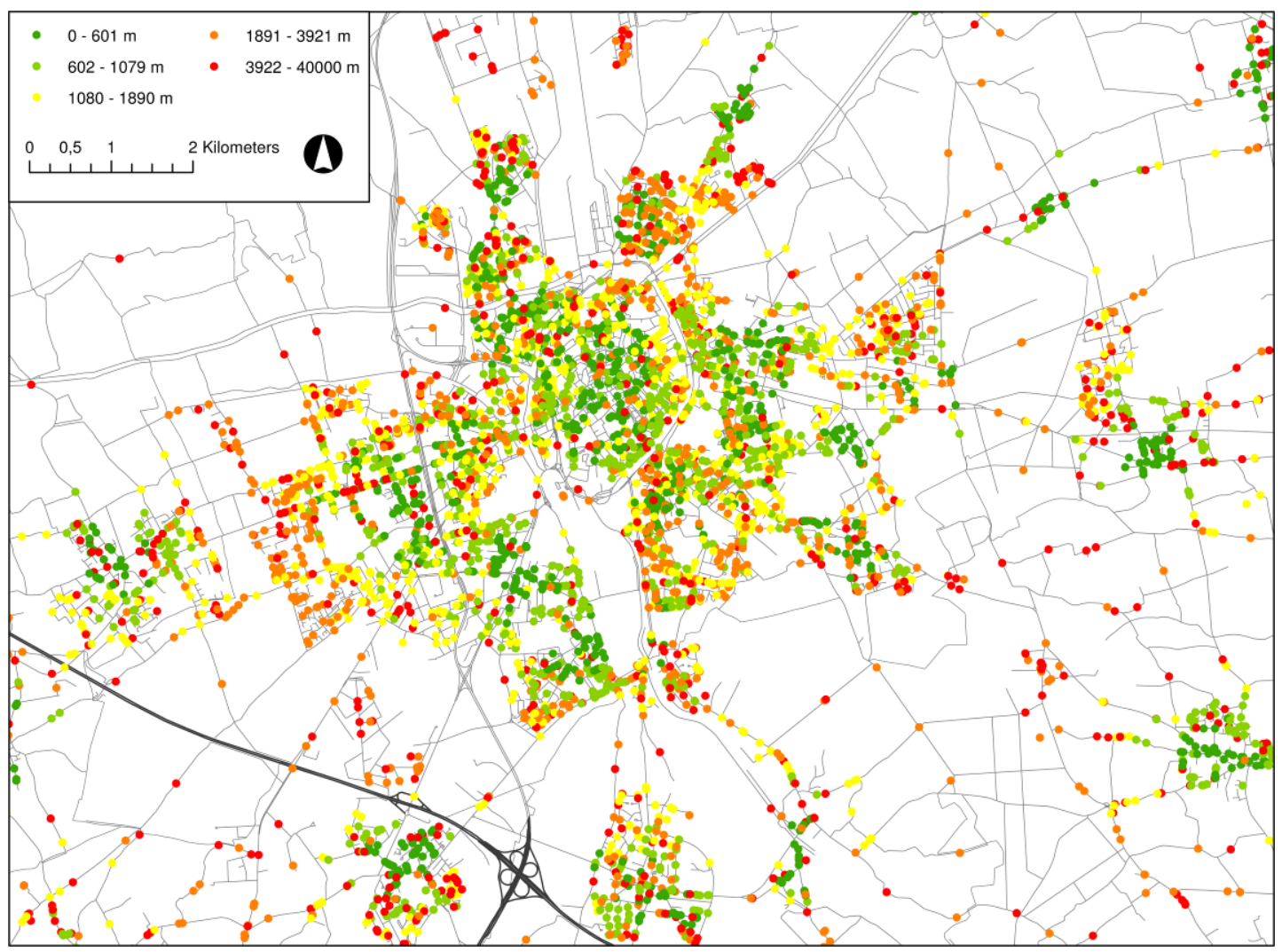

Fig. 6. Observed home-school distance by pupil, Bruges and surroundings 


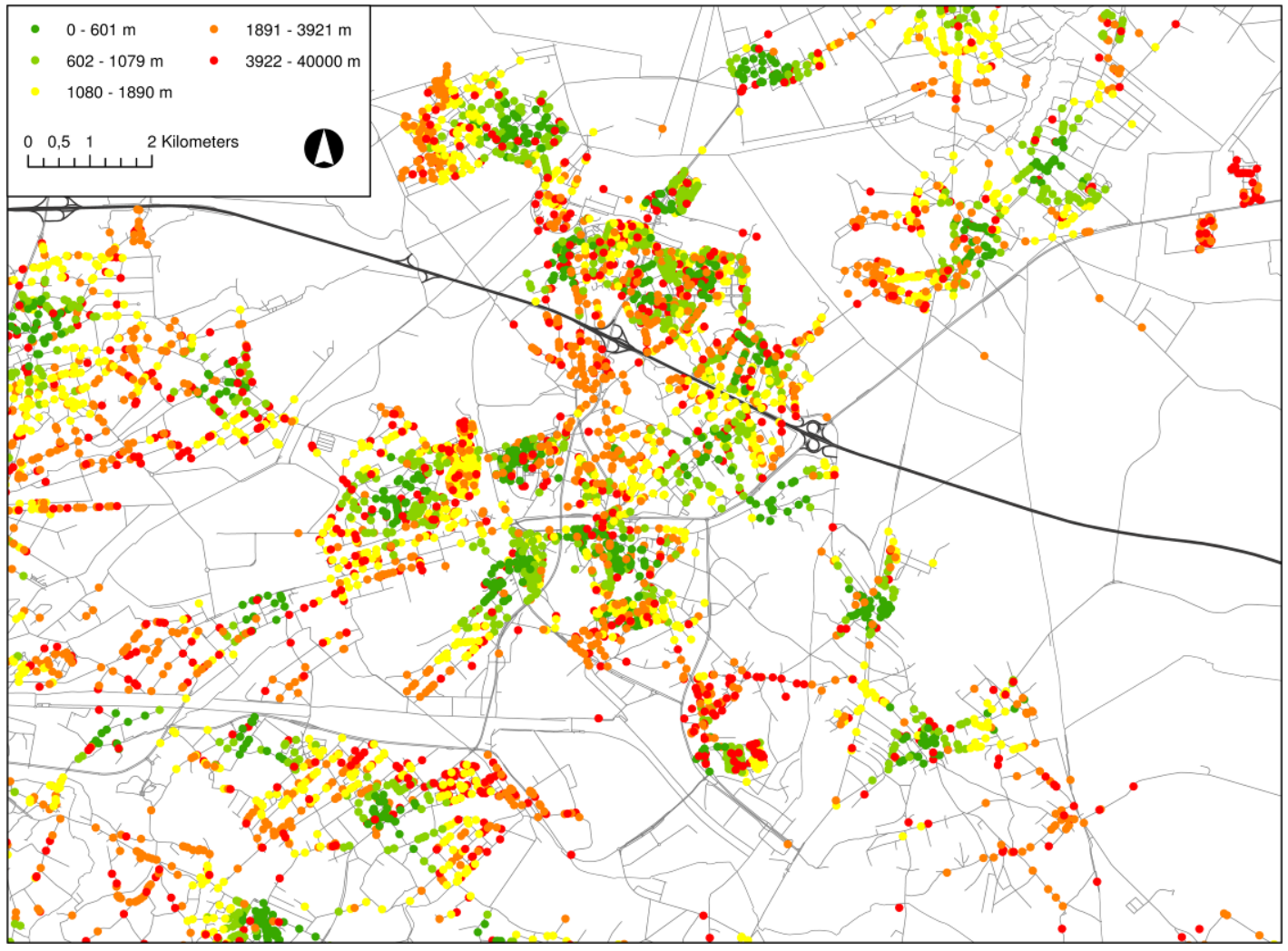

Fig. 7. Observed home-school distance by pupil, Genk and surroundings

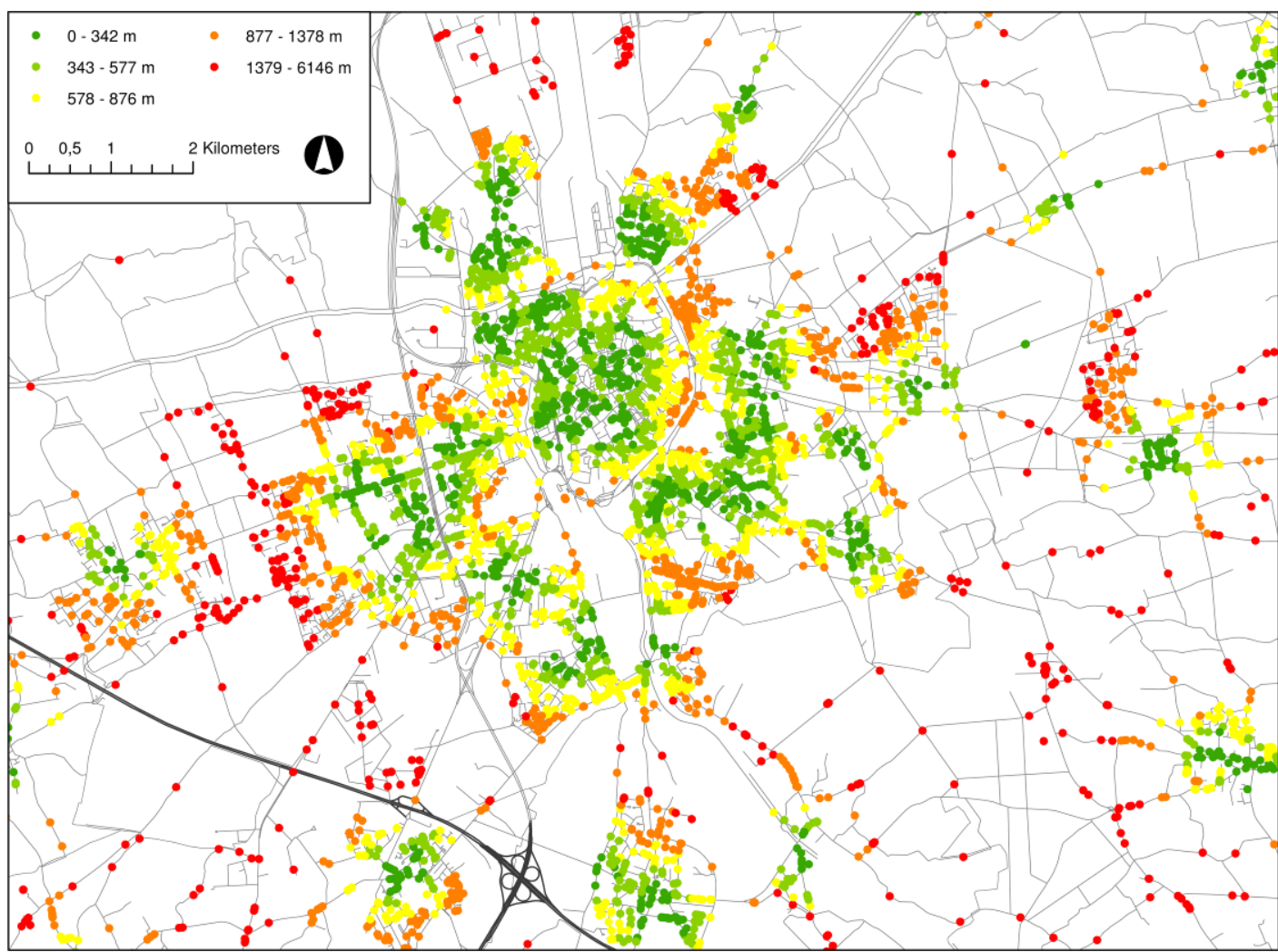

Fig. 8. Minimum home-school distance by pupil, Bruges and surroundings 


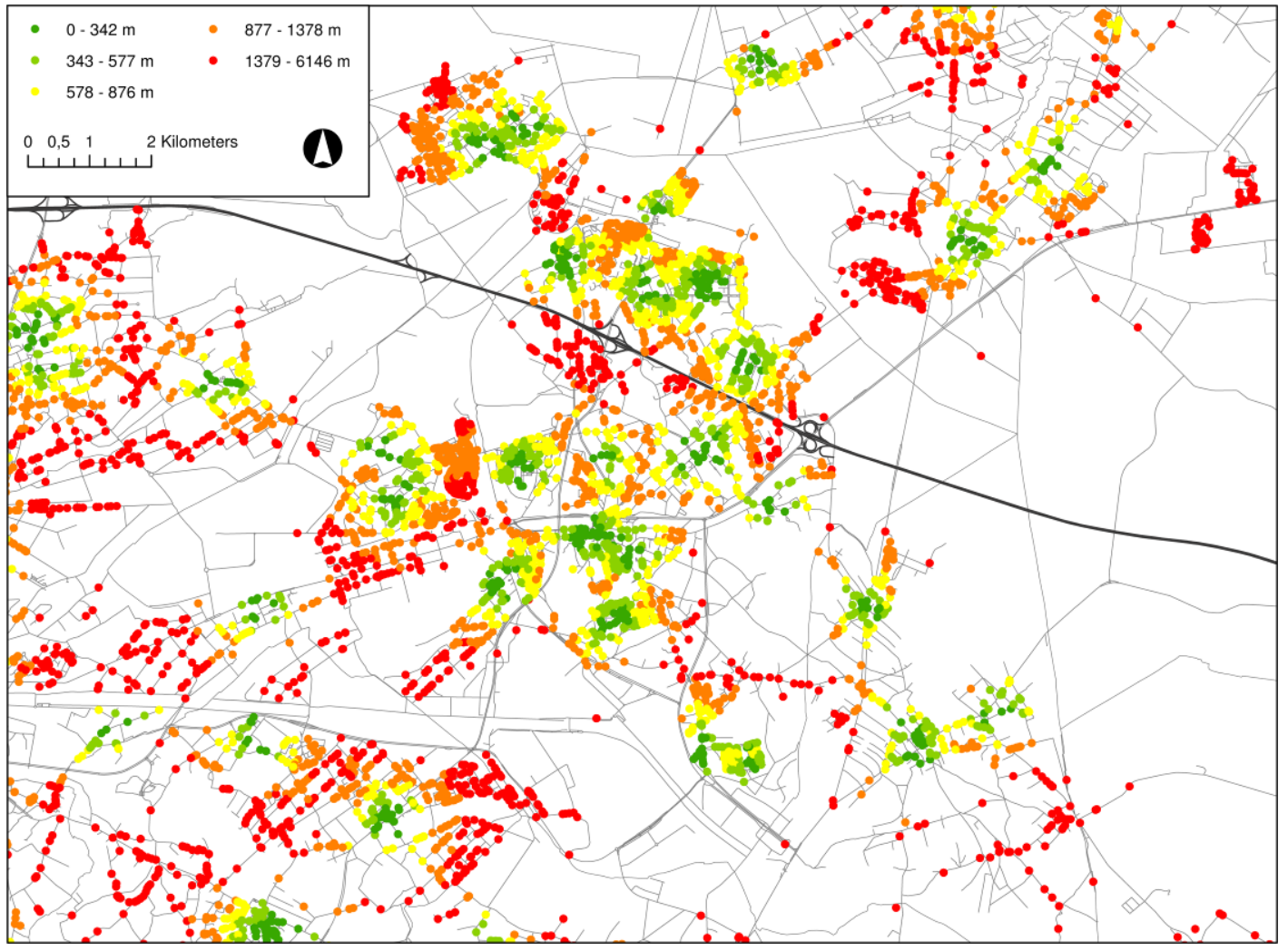

Fig. 9. Minimum home-school distance by pupil, Genk and surroundings

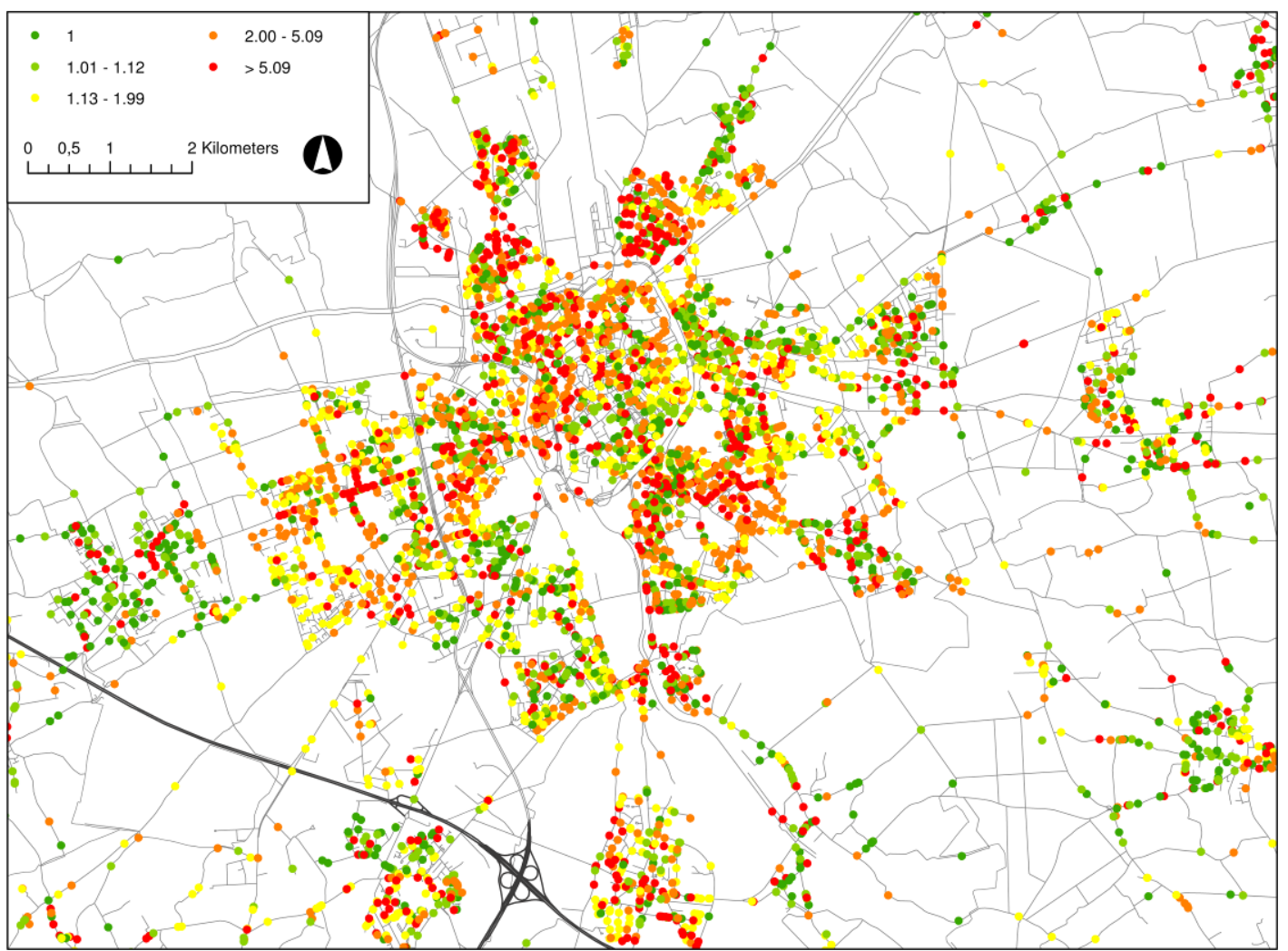

Fig. 10. Excess rate by pupil, Bruges and surroundings 


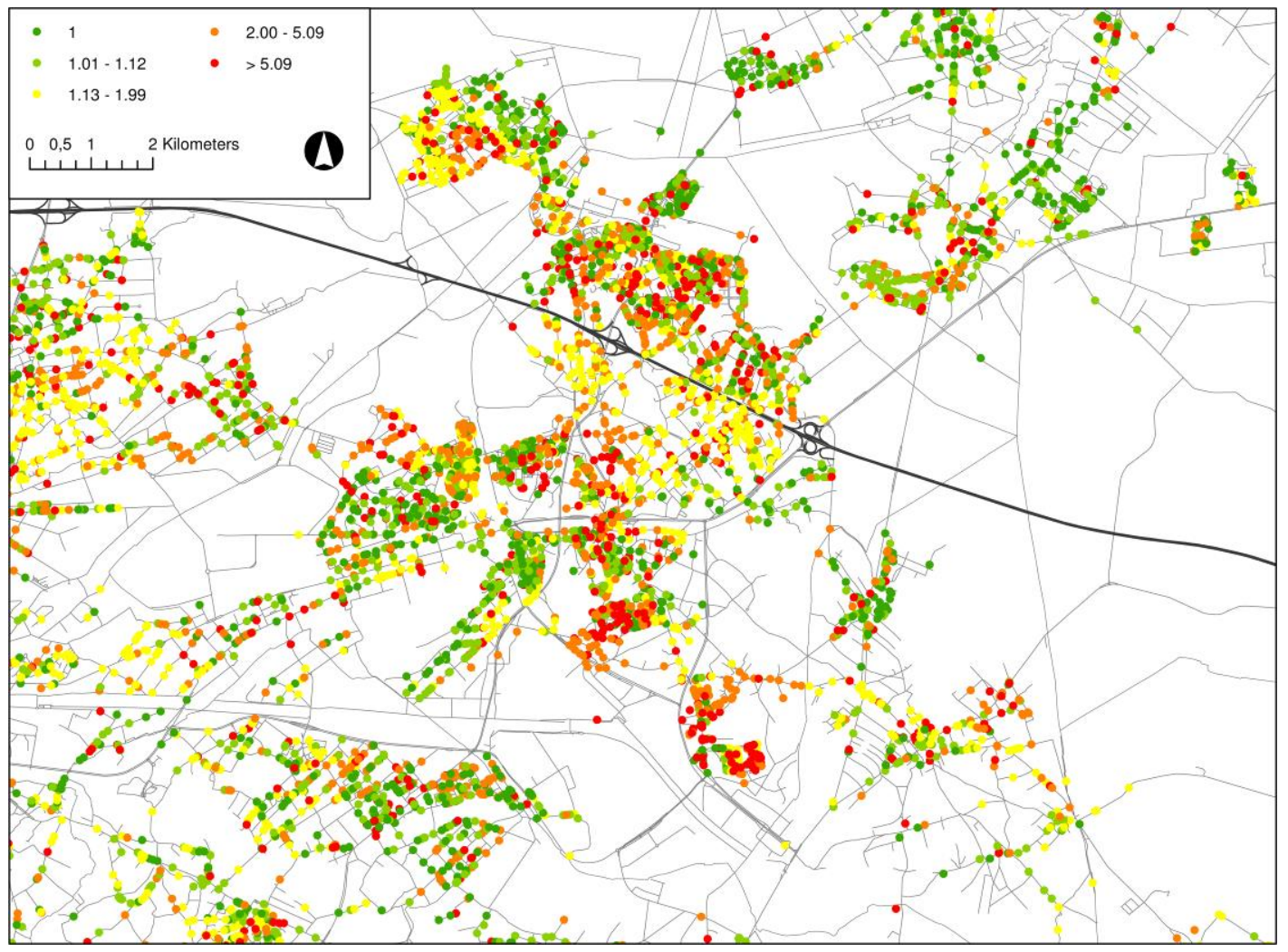

Fig. 11. Excess rate by pupil, Genk and surroundings

\begin{tabular}{|l|r|r|r|}
\hline & $\begin{array}{r}\text { observed home- } \\
\text { school distance }\end{array}$ & $\begin{array}{r}\text { minimum home- } \\
\text { school distance }\end{array}$ & excess rate \\
\hline median & $1394 \mathrm{~m}$ & $710 \mathrm{~m}$ & 1.41 \\
\hline mean & $2752 \mathrm{~m}$ & $946 \mathrm{~m}$ & 6.14 \\
\hline standard deviation & $4037 \mathrm{~m}$ & $1017 \mathrm{~m}$ & 68.13 \\
\hline
\end{tabular}

Table 5. Statistics on the observed home-school distance, minimum home-school distance, and excess rate by pupil 


\begin{tabular}{|l|r|r|r|r|r|r|r|}
\hline class & MA & RUA & SSUA & PSUA & NOA & OA & outside \\
\hline $\begin{array}{l}\text { number of } \\
\text { pupils }\end{array}$ & 76545 & 45272 & 18611 & 15095 & 150165 & 63544 & 4829 \\
\hline $\begin{array}{l}\text { median obs. } \\
\text { home-school } \\
\text { distance }\end{array}$ & $\begin{array}{r}1078 \\
\mathrm{~m}\end{array}$ & $\begin{array}{r}1165 \\
\mathrm{~m}\end{array}$ & $\begin{array}{r}1156 \\
\mathrm{~m}\end{array}$ & $\begin{array}{r}1094 \\
\mathrm{~m}\end{array}$ & $1307 \mathrm{~m}$ & 2289 & $7768 \mathrm{~m}$ \\
\hline $\begin{array}{l}\text { median min. } \\
\text { home-school } \\
\text { distance }\end{array}$ & $427 \mathrm{~m}$ & $572 \mathrm{~m}$ & $614 \mathrm{~m}$ & $629 \mathrm{~m}$ & $753 \mathrm{~m}$ & 1415 & $4950 \mathrm{~m}$ \\
\hline $\begin{array}{l}\text { median excess } \\
\text { rate }\end{array}$ & 2.14 & 1.65 & 1.56 & 1.36 & 1.19 & 1.24 & 1.32 \\
\hline
\end{tabular}

Table 6. Statistics by pupil, by degree of urbanization. The class "outside" contains those pupils not living in Flanders or Brussels

The different spatial structure of both case study areas becomes clear when comparing Fig. 8 with Fig. 9. The historical structure of Bruges is responsible for the high density of both homes and schools. In the core of the city we see that the catchment areas of clustered schools overlap, causing a large proportion of the students having the choice between several schools within walking distance. Also in the historical village belt around Bruges, where a considerable share of the post-1945 suburbanization wave was directed to, the available range of schools is rather wellcovering. Only pupils who live in a recent allotment, or who live very remote, are required to cover distances over $1400 \mathrm{~m}$. In Genk, however, we see a very different picture: there is no cluster of schools in the centre of the city. The population density in the inner city's residential neighbourhoods is relatively low, and usually each neighbourhood has only one school. The map turns strikingly red, which indicates that the spatial structure of Genk does not perform well in terms of spatial proximity compared to Bruges. Lower density figures in combination with the absence of clusters of schools also ensures that choice ranges in Genk are more limited than in Bruges.

When looking at the excess rates, in Bruges (Fig. 10) pupils living in the core city or in one of the sub-centres of the agglomeration, appear to visit the nearest school less often than average. In Genk (Fig. 11), however, such structures are less clear; pupils 
usually opt for the nearest school despite living in centrally located neighbourhoods. One of the causes may be Genk's more extensive fragmentation by infrastructure. Even when studying the observed home-school distance (Fig. 6 and 7), it is obvious that in Genk the theoretical catchment areas (Fig. 8 and 9) are better reflected in the observed travel patterns than is the case in Bruges. From a CPT perspective, in Genk we can say that the combination of school availability and upper limit of the range tends to lead to a situation of spatial monopoly, whereas in the more centralized situation of Bruges, from a spatial perspective, there is a potentiality for school choice within the average time-space budget.

The home-school distance statistics in Table 5 are of the same order of magnitude as the values already presented in Table 3 . Also, the values of Table 6 correspond fairly well with those of Table 4 . It is striking that $58 \%$ of the Dutch-language pupils in Flanders or Brussels live outside any urban area. However, the share of them (70\%) living in a nucleus in the outlying area, usually corresponding with a village, hardly suffer from their peripheral residential location: half of these pupils still choose a school at $1300 \mathrm{~m}$ or less from home, and is faced with the possibility to further reduce this distance to a mere $750 \mathrm{~m}$. For those living outside such a nucleus (17\% of the pupils in Flanders and Brussels), in contrast, the remote home location is responsible for the relatively large home-school distance, affecting the autonomy of the child concerned. Pupils living in Wallonia or abroad are naturally obliged to cover above average distances. Since this category of pupils includes some rather inaccurate data, we will draw no further conclusions from the figures for this "outside" class.

Excess rates roughly decrease when the degree of urbanization increases. This means that, as expected, pupils living more remotely choose more often the nearest school, which corresponds to the observations made on the basis of Table 4 . 


\section{Conclusions and policy recommendations}

Based on the analysis of detailed information about the home-school distances in the Flemish primary education system in Belgium, we are able to answer both research questions. With regard to the first question, we note that at the level of the pupil there is a strong correlation between the minimum home-school distance, which defines the theoretical minimal catchment area of a school, and the observed home-school distance, which represents the real catchment area. Taking into account that schools are often part of a cluster of local amenities, this indicates that the spatial distribution of the primary schools seems to correspond to a certain extent with the pattern that is expected from CPT, corroborating that lower order central functions and places retain analytical relevance. Depending on local properties of the spatial structure, at this level central places are represented by either one school (as is the case in Genk), or by a cluster of schools located within walking distance of each other (as is the case in the centre of Bruges). This corresponds with the historical urbanization trajectory of these two urban areas. Although the school's real catchment areas, defined by the observed home-school distances, largely overlap, this overlap is mainly occurring at the local level, in contrast with home-work commute areas which overlap at the regional scale. Also striking is that theoretical and real catchment areas better match up where the surface covered by these areas is larger, especially in the nuclei of the outlying area.

With regard to the second question, the research presents arguments to conclude that the spatial distribution of the Dutch-language primary schools in Belgium is quite well adapted to a sustainable form of home-school travel, based on short distances. The order of magnitude of the median observed and minimum home-school distances allows travel on foot or by bicycle (Cardon et al., 2012), and almost every village core has at least one primary school.

Nevertheless, a few qualifications apply. First, mainly in the 1980s, the rationalization of the primary education system has led to a systematic increase of the average distance between home and the nearest school, a development that has contributed to further motorization of schoolchildren's travel behaviour. Second, the housing stock kept suburbanizing during the last decades, which again contributed to 
the growth of home-school distances. Third, it is still possible to identify a number of villages and residential neighbourhoods that are quite remote from any primary school, locally qualifying the coverage of the school network as below average or even insufficient.

We also see that quite a few schools located in an urban area represent relatively large home-school distances. This phenomenon can be partly explained through parents choosing a school for their children on the route of their own commute. In addition, this may indicate a shortage of primary education facilities in some inner cities, particularly in Brussels (Janssens, 2009), but also in Antwerp and Ghent, where schools are often fully booked. This reduces the chance that a child can be enrolled in the school of choice, often the nearest one. The problem of ethnically segregated schools, which are often avoided by autochthonous pupils, reinforces this phenomenon (Van Houtte and Stevens, 2009). A good spatial distribution of schools does not mean that there are no local problems in terms of capacity or social and ethnic segregation.

Finally, the literature review suggests a clearly autonomous growth of home-school mobility, which is at least partly independent from the spatial distribution of schools and homes. The overall increase in mobility, which is caused by various factors, including the rise of prosperity and a more critical consumer's attitude, is present too in the school commute. In practice this is reflected in the increasing number of children taken to school by car, with the commonly known vicious circle of increasing car use (Sonkin et al., 2006) as a result.

Although the primary school network's rather high density, as well as the elevated level of proximity between schools and homes in Flanders should generally be considered as an important quality of place, the spatial distribution of this asset is not homogeneous. In order to maintain the general quality, and in order to ensure a more equal spatial distribution, policy measures are needed. In addition to the well-known ingredients of a compact city policy, such as avoiding sprawl, offering a dense network of amenities and facilitating non-motorized trips, from our study also some less obvious issues are addressed. One of these is the importance of sufficient supply in terms of school capacity, in order to avoid inefficient home-school travel. It is equally important to keep the quality of education as uniform as possible across 
municipalities, in order to avoid parents choosing distant schools for quality reasons. Lastly, when considering further consolidation of the school network, it should be taken in account that costs saved at the operational level of the school may well be passed in a hardly visible way to the pupils' parents and even to society in general in the form of additional transport related burden. It is our conviction that the latter theme offers a challenging avenue for further research.

\section{References}

Banister, D., Watson, S., \& Wood, C. (1997). Sustainable cities: Transport, energy, and urban form. Environment and Planning B, 24(1), 125-143.

Berry, B. J. L., \& Garrison, W. (1958). Recent developments of central place theory. Papers in Regional Science, 4(1), 107-120.

Berry, B. J. L., Parr, J. B., Epstein, B. J., Ghosh, A., \& Smith, R. H. T. (1988). Market Centers and Retail Location. Eaglewood Cliffs, NJ: Prentice Hall.

Bertaud, A. (2004). The spatial organization of cities: Deliberate outcome or unforeseen consequence? Berkeley, CA: Institute of Urban and Regional Development, UC Berkeley.

Bontje, M. (2004). From suburbia to post-suburbia in the Netherlands: Potentials and threats for sustainable regional development. Journal of Housing and the Built Environment, 19(1), 25-47.

Boussauw, K. (2011). Aspects of spatial proximity and sustainable travel behaviour in Flanders : A quantitative approach. PhD Thesis. Ghent: Ghent University.

Boussauw, K., Derudder, B., \& Witlox, F. (2011). Measuring spatial separation processes through the minimum commute: The case of Flanders. European Journal of Transport and Infrastructure Research, 11(1), 42-60.

Boussauw, K., Van Acker, V., \& Witlox, F. (2012). Excess travel in non-professional trips: Why look for it miles away? Tijdschrift voor Economische en Sociale Geografie, 103(1), 20-38.

Burger, M. J., Meijers, E. J., \& Van Oort, F. G. (2013). Regional spatial structure and retail amenities in the Netherlands. Regional Studies, in press.

Cardon, G. M., Maes, L. R. D., Haerens, L. L., \& Bourdeaudhuij, I. M. M. D. (2012). Bicycling to school during the transition from childhood into adolescence: a six-year longitudinal study. Pediatric Exercise Science, 24(3), 369-383.

Cervero, R., \& Duncan, M. (2006). Which reduces vehicle travel more: Jobs-housing balance or retail-housing mixing? Journal of the American Planning Association, 72(4), 475-490.

Cervero, R., \& Wu, K.-L. (1997). Polycentrism, commuting, and residential location in the San Francisco Bay area. Environment and Planning A, 29(5), 865-886.

Christaller, W. (1966 [1933]). Central Places in Southern Germany. Eaglewood Cliffs, NJ: Prentice Hall.

De Boer, E. (2010). School Concentration and School Travel. PhD Thesis. Delft: Delft University of Technology. 
Dujardin, S., Boussauw, K., Brévers, F., Lambotte, J.-M., Teller, J., \& Witlox, F. (2012). Sustainability and change in the institutionalized commute in Belgium: Exploring regional differences. Applied Geography, 35(1-2), 95103.

Ewing, R., \& Greene, W. (2003). Travel and environmental implications of school siting. Washington, DC: United States Environmental Protection Agency.

Flemish Ministry of Education and Training. (2013). Statistisch jaarboek van het Vlaams onderwijs - schooljaar 2011-2012. Brussel: Flemish Government.

Glenn, C. L. (1989). Choice of Schools in Six Nations: France, Netherlands, Belgium, Britain, Canada, West Germany. Washington, DC: Office of Educational Research and Improvement.

Hall, P. (2002). Christaller for a global age: Redrawing the urban hierarchy. In A. Mayr, M. Meurer \& J. Vogt (Eds.), Stadt und Region: Dynamik von Lebenswelten (pp. 110-128). Leipzig: Deutsche Gesellschaft für Geographie.

Halleux, J.-M., Lambotte, J.-M., Rixhon, G., \& Mérenne-Schoumaker, B. (2009). Pendel in België: De Woon-Schoolverplaatsingen. Brussels: FPS Economy Directorate-General Statistics and Economic Information.

Horner, M. (2002). Extensions to the concept of excess commuting. Environment and Planning A, 34(3), 543-566.

Janssens, D., Cools, M., Miermans, W., Declercq, K., \& Wets, G. (2011). Onderzoek Verplaatsingsgedrag Vlaanderen 4.2 (2009-2010). Brussels-Diepenbeek: Flemish Government.

Janssens, R. (2009). Onderzoek naar de capaciteit van het Nederlandstalig basisonderwijs in het Brussels Hoofdstedelijk Gewest. Brussel: Brussels Informatie-, Documentatie- en Onderzoekscentrum.

Karsten, L. (2007). Housing as a way of life: Towards an understanding of middleclass families' preference for an urban residential location. Housing Studies, 22(1), 83-98.

Krizek, K. J. (2003). Neighborhood services, trip purpose, and tour-based travel. Transportation, 30(4), 387-410.

Lambooy, J. G. (1969). City and city region in the perspective of hierarchy and complementarity. Tijdschrift voor Economische en Sociale Geografie, 60(3), 141-154.

Leemans, G. (1998). Scholenbouw in de Vlaamse Gemeenschap: De behoefte aan scholenbouw binnen het gesubsidieerd vrij en officieel onderwijs. Brussels: Dienst voor Infrastructuurwerken van het Gesubsidieerd Onderwijs.

Marique, A.-F., Dujardin, S., Teller, J., \& Reiter, S. (2013). School commuting: The relationship between energy consumption and urban form. Journal of Transport Geography, 26, 1-11.

Mérenne-Schoumaker, B., Van der Haegen, H., \& Van Hecke, E. (1999). Algemene Volks-en woningtelling op 1 maart 1991: Werk- en schoolpendel. Brussel: Nationaal Instituut voor de Statistiek.

Müller, S. (2011). Assessment of school closures in urban areas by simple accessibility measures. Erdkunde, 65(4), 401-414.

Neuman, M. (2005). The compact city fallacy. Journal of Planning Education and Research, 25(1), 11-26. 
Neutens, T., Versichele, M., \& Schwanen, T. (2010). Arranging place and time: A GIS toolkit to assess person-based accessibility of urban opportunities. Applied Geography, 30(4), 561-575.

Reginster, I., \& Goffette-Nagot, F. (2005). Urban environmental quality in two Belgian cities, evaluated on the basis of residential choices and GIS data. Environment and Planning A, 37(6), 1067-1090.

RSV. (2004[1997]). Ruimtelijk Structuurplan Vlaanderen. Brussels: Ministry of the Flemish Community.

Saey, P. (1973). Three fallacies in the literature on central place theory. Tijdschrift voor Economische en Sociale Geografie, 64(3), 181-194.

Sonkin, B., Edwards, P., Roberts, I., \& Green, J. (2006). Walking, cycling and transport safety: an analysis of child road deaths. Journal of the Royal Society of Medicine, 99(8), 402-405.

Stead, D., \& Marshall, S. (2001). The relationships between urban form and travel patterns: An international review and evaluation. European Journal of Transport and Infrastructure Research, 1(2), 113-141.

Stern, E., \& Michlis, M. (1986). Redefining high school catchment areas with varying effects of achievement equality. Applied Geography, 6(4), 297-308.

Van Acker, V., \& Witlox, F. (2013). Car ownership as a mediating variable in car travel behaviour research using a structural equation modelling approach to identify its dual relationship. Journal of Transport Geography, 18(1), 65-74.

Van Damme, D. (1999). Massificatie, democratisering en rationalisering: Het schoolpact en de paradoxen van de onderwijsexpansie. In E. Witte, J. De Groof \& J. Tyssens (Eds.), Het Schoolpact van 1958 - Le Pacte Scolaire de 1958 (pp. 787-819). Brussels: Garant - VUBPress.

Van Diepen, A. M. L., \& Musterd, S. (2009). Lifestyles and the city: Connecting daily life to urbanity. Journal of Housing and the Built Environment, 24(3), 331-345.

Van Houtte, M., \& Stevens, P. A. J. (2009). School ethnic composition and students' integration outside and inside schools in Belgium. Sociology of Education, 82(3), 217-239.

Van Nuffel, N., \& Saey, P. (2005). Commuting, hierarchy and networking: The case of Flanders. Tijdschrift voor Economische en Sociale Geografie, 96(3), 313327.

Zwerts, E., Allaert, G., Janssens, D., Wets, G., \& Witlox, F. (2010). How children view their travel behaviour: A case study from Flanders (Belgium). Journal of Transport Geography, 18(6), 702-710. 